\title{
UNEQUAL PATTERNS OF DEVELOPMENT OF SUCCINATE-DEHYDROGENASE AND ACETYLCHOLINESTERASE IN PURKINJE CELL BODIES AND GRANULE CELLS ISOLATED IN BULK FROM THE CEREBELLAR CORTEX OF THE IMMATURE RAT $^{1}$
}

\author{
O. Z. Sfllinger, ${ }^{2}$ J. Legrand, ${ }^{3}$ J. Clos $^{3}$ and W. G. Ohl.sson ${ }^{2}$ \\ 'Laboratory of Neurochemistry, Mental Health Research Institute, The University of \\ Michigan Medical Center, Ann Arbor. MI 48104, U.S.A. and ${ }^{3}$ Laboratoire de Physiologie Comparée. \\ Université des Sciences et Techniques du Languedoc, 34060 Montpellier Cedex, France
}

(Received 17 January 1974. Accepted 25 April 1974)

\begin{abstract}
A preparative procedure for the isolation in bulk of two cellular populations of the cerebellar cortex of the immature rat, the granule cells and the Purkinje cell bodies, is described. The procedure is used to delineate the developmental pattern of succinate-INT-reductase (EC 1.3.99.1) and acetylcholinesterase (EC 3.1.1.7) in the crucial period of cerebellar maturation, i.e. between 12 and 19 days postnatally. Although the overall yield of neuronal RNA diminished with age. the proportion of RNA in the Purkinje cell body fraction increased while that in the granule cells decreased and microscopic examination of the fractions confirmed this result. The yields of succinate-INT-reductase and of acetylcholinesterase in the fractions paralleled the yields of RNA. A significant finding was the trend toward diminishing specific activities (units/ $\mu$ g of RNA) with age of both enzymes in the Purkinje cell bodies as against the opposite. upward trend of their specific activities in the granule cells. An additional finding of interest was the different ratio of true acetylcholinesterase/total cholinesterase activity in the two cell types, with the granule cells consistently exhibiting higher true acetylcholinesterase values than the Purkinje cell bodies. The present report thus supplements the histoenzymological data on the developing rat cerebelium in that it reveals specific differences in the enzymatic development of two different cerebellar types. a finding which was greatly facilitated by the availability of the procedure for their bulk isolation.
\end{abstract}

ALTHOUGH in the past few years several techniques for the bulk-isolation of purified nerve cell bodies and glial cells from vertebrate brain have been reported (see reviews by PODUSLo \& Norton. 1972, and by SELLINGER and ALCURRA, 1974), an assessment of the spectrum of their potential uses and applications in research in cellular neurochemistry is still largely outstanding. Since the laboratories in Montpellier and Ann Arbor share common interests in that research in the former focuses on studies of the influence of hormonal and nutritional manipulations on the maturation of specific cerebellar elements (LEGRAND, 1967; Rebièrf, \& Legrand. 1970, 1972; Clos. 1972; Clos \& Legrand. 1973; Clos et al., 1973), while in the latter

1 This work was supported by grant No. NS-06294 from the United States Public Health Service and grant No. 72.07.102 from the D.G.R.S.T., France.

Ahbreviarions used: BSA, bovine serum albumin: PVP. polyvinylpyrrolidone. it explores the significance and the determining nature of cell-specific patterns of enzymatic composition on neuronal development (IDoyaga-Vargas et al.. 1972: Shllinger \& Santiago, 1972; Mrdzlhradosky et al., 1972; Sellinger et al, 1973), collaboration between the two laboratories was recently initiated for the purpose of uncovering neurochemical parameters which might be involved in the specific characterization of the development and maturation of functionally different nerve cells. For this investigation the granule cells and the Purkinje cells of the immature rat cerebellar cortex were selected. The present report outlines a newly developed procedure for the bulk-isolation of granule cells and of Purkinje cell bodies and illustrates the use of this procedure in the discovery of significant differences between the developmental patterns of two of their enzymatic activities. succinate dehydrogenasc (EC 1.3.99.1) and acetylcholinesterase (EC 3.1.1.7). COHEv et al. (1973) and Yavagihara \& HambirgtifR (1973) have recently also described procedures for the 
preparation of purified cerebellat eells. but neither group has reported any findings dealing with their specific enzymatic composition. Some of our present results thus extend previous studies carried out with hand-dissected cellular layers of the adult cerebellar cortex (SHLtik. et al. 1970): Sellivger et al. 1972; Hiksch. 1972) as well as a number of related histochemical developmental studies (LEGRAND. 1967: AlTMAN \& DAS, 1970: CLOS, 1972).

\section{MATERIALS AND METHODS}

thimals and matcrials

Wistar rats of both sexes (strain CF of the Centre National de la Recherche Scientifique. France) were used. The length of the gestation period and the exact timing of the birth dates of the litters were carefully controlled.

Bovine serum albumin (BSA, fraction V) was obtained from Pentex Biochemicals. Kankakee. Illinois. and polyvinylpyrrolidone (PVP. Plasdone C. average mol. wt 40.000) from GAF Corporation. Calvert City. Kentucky. Sucrose and calcium chloride were analytical reagent grade from Merck and Co.. Darmstadt, W. Germany. Nylon bolting cloth was purchased from Tobler. Ernst and Traber. Elmsford, New York. 2(p-lodophenyl)-3(p-nitrophenyl15phenyl tetrazolium chloride (INT) and acetylthiocholine iodide were purchased from Sigma Co.. St. Louts. Missouri. The specific inhibitor of acetylcholinesterase BW $62 \mathrm{C} 47$ [1:5 bis(4-trimethylammonium phenylipentane-3-one ] diiodide was a gift from the Burroughs-Welcome $\mathrm{Co}$.

\section{Muthods}

Analyical. RNA was measured by the procedure of Flfick \& Begg; (1965). A factor of 41.6 was used to convert the $A_{260}$ readings (taken in a final volume of $1.3 \mathrm{ml}$ ) to $\mu \mathrm{g}$ of R NA ml. A correction was also applied for the contribution of fraction V BSA to the absorbance at $260 \mathrm{~nm}$.

Enzymes. Succinate dehydrogenase was determined as succinate-INT-reductase according to SELLINGER \& HIATT (1968). The procedure of ElLMaN et al. (1961) was used to determine total and true acetylcholinesterase. For this purpose. in each experiment half of the tubes were incubated in the presence of the specific acetylcholinesterase inhibitor BW $62 \mathrm{C} 47\left(1 \times 10^{-4} \mathrm{M}\right)$ and the $\mathrm{A}_{412}$ values obtained in these tubes were subtracted from those obtained in tubes incubating in the absence of the inhibitor. In addition, since tubes containing sucrose in excess of $0-1 \mathrm{~m}$ gave appreciable readings at $412 \mathrm{~nm}$ when carried through the assay procedure. it was necessary to apply separate corrections for each cell fraction in which the enzymatic activity was to be determined. These were read off a calibration curve relating the absorbance at $412 \mathrm{~nm}$ to the molarity of the sucrose in the samples to be assayed. All units of enzyme activity are defined operationally as the $\mathrm{A} / \mathrm{ml}$ per incubation time (specified in the legends). Specific activities are expressed as units/ $\mu$ g of RNA. rather than per mg of protein, the principal reason for this being the presence of $0-1$ per cent fraction
$V$ BSA in all the solutions used to prepare the cell fractions (see Results for additional reasons).

Isolation of Purkinje cell bodies and yramile cells. The procedure was adapted from that described previously (SFLLiNGer et ul., 1971: JOHNSON \& SFLLINGer. 1971) for the preparation of nerve cell bodies from the cerebral cortex. A representative run is described below. Twenty cerebellar cortices were weighed. placed on an inverled Petri dish resting on crushed ice and covered with a piece of premoistencd Whatman No. 1 filter paper and were chopped with a prechilled razor blade into the consistency of a mince.

The mince was transferred into $4-5 \mathrm{ml}$ of an ice-cold solution of $7.5^{\circ}{ }_{\circ}(w / v)$ polyvinylpyrrolidone (PVP). $1^{\circ}{ }_{0}(w / v)$ BSA and $3.77 \mathrm{mM} \mathrm{Ca}^{2+}$. The resulting suspension was decanted into a truncated plastic syringe of the type described previously (Sellinger et al.. 1971) and was pushed manually through a series of nylon filters 133,110 and $74 \mu \mathrm{m}$ pore size) also described previously (SELLINGER et $a l$. 19711, with three successive passes through each filter. Three $2.6-3.0 \mathrm{ml}$ aliquots of the sieved cerehellar suspension. representing about 90 per cent of its volume. were then carefully layered on a 3 -step gradient of $0.5 \mathrm{ml}$ of $2.30 \mathrm{M}$ sucrose in $1{ }^{\circ}$ "BSA, $1.5 \mathrm{ml}$ of $1.75 \mathrm{M}$ sucrose in $1^{\prime \prime}$ "BSA and $0.6 \mathrm{ml}$ of $1.00 \mathrm{M}$ sucrose in $1^{\circ}{ }_{0} \mathrm{BSA}$ and the tubes were centrifuged in the $3 \times 5 \mathrm{ml}$ swing-out rotor of the MSE centrifuge at $41.000 \mathrm{~g}$ for $30 \mathrm{~min}$. The rather fine band of material at the $1.75 \mathrm{M}-2.30 \mathrm{M}$ sucrose interface is the fraction of mixed neurons and is retained while the more voluminous bands at the two upper interfaces are discarded. After their removal by slight negative pressure of a water aspirator. the mixed neuron fraction was aspirated manually by means of a capillary Pasteur pipette and was diluted with hall of its
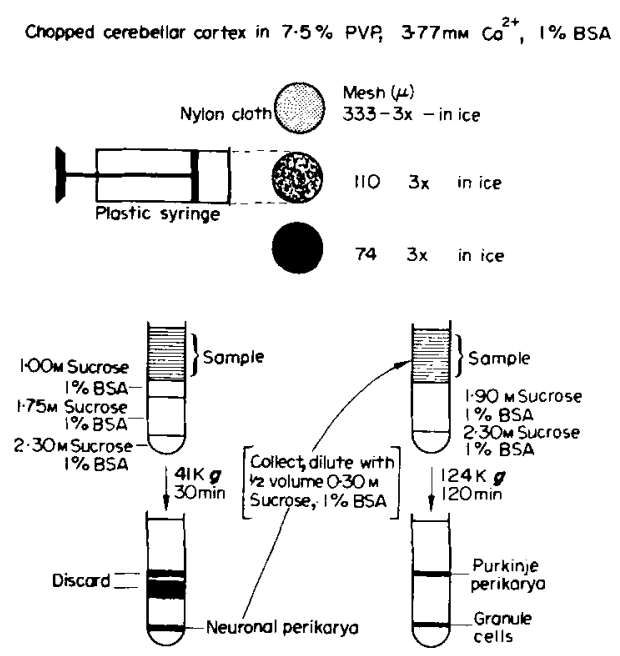

FIG. 1. Schematic outline of the procedure for the bulkpreparation of Purkinje cell bodies and granule cells from the cerebellar cortex of 12-24-day-old rats. PVP: polyvinylpyrrolidone: BSA: fraction V. bovine serum alhumin (sec Materials): $\mathrm{K}: 1000$. 


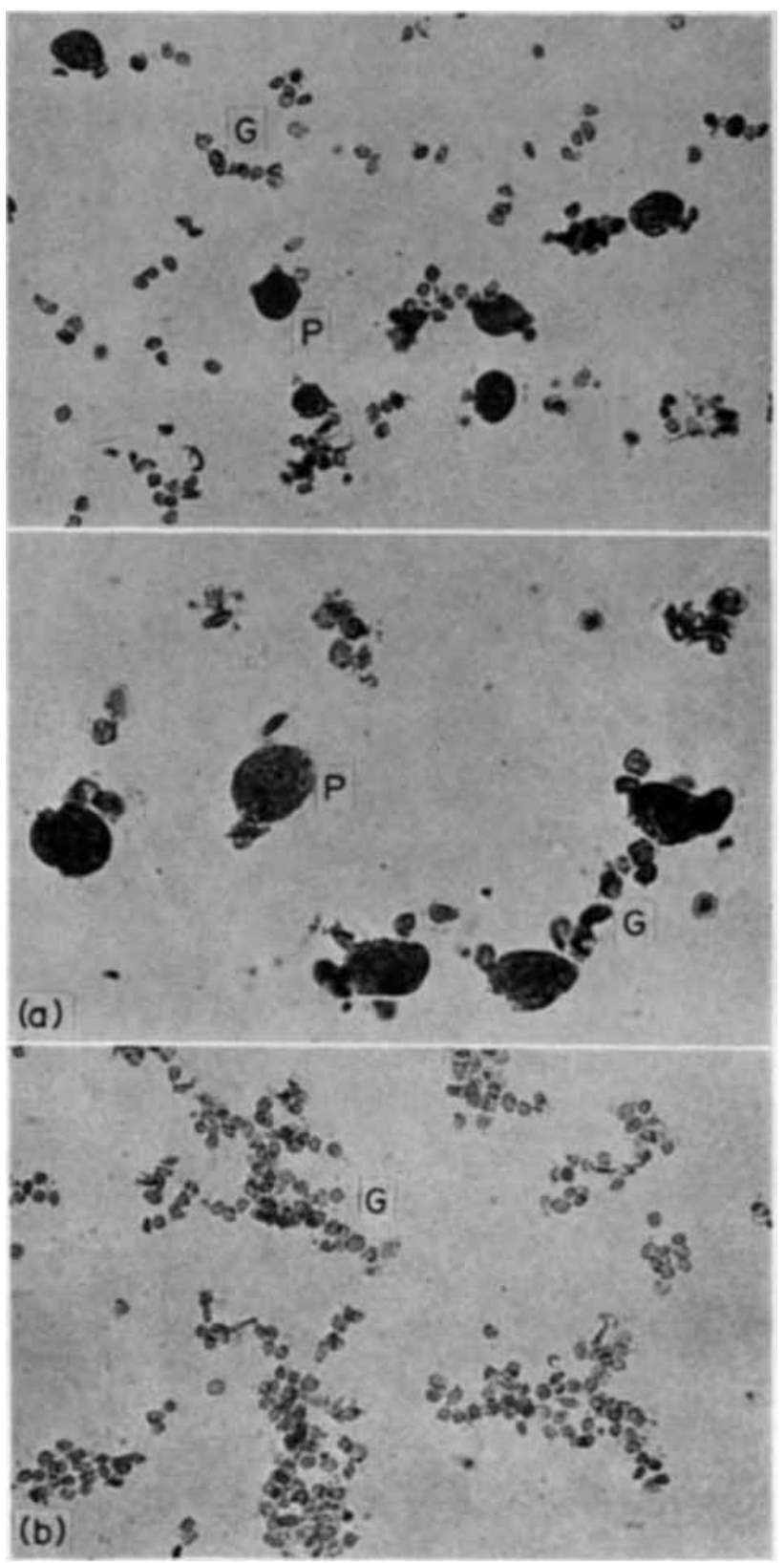

FIG. 2. The appearance of the cell fractions after cresyl violet staining (a-c) and under phase contrast $(d-f)$. (a) mixed neuronal fraction, 15 days. 560 and $\because 900$. (b) Granule cells (G) 13 days. $\because 560$. 


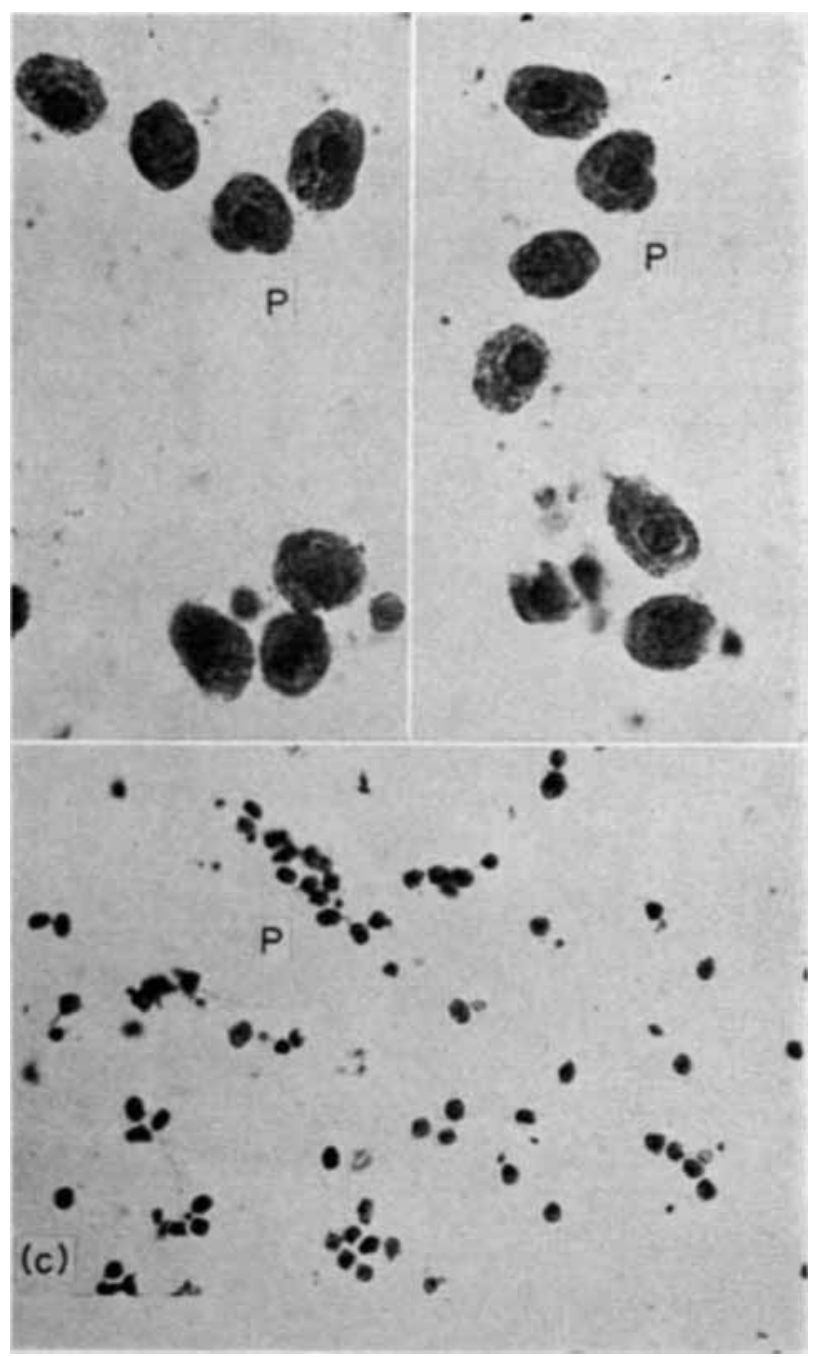

Fig. 2. (c) Purkinje cell bodies (P), 18 days. $\times 225$ and $\times 900$. 

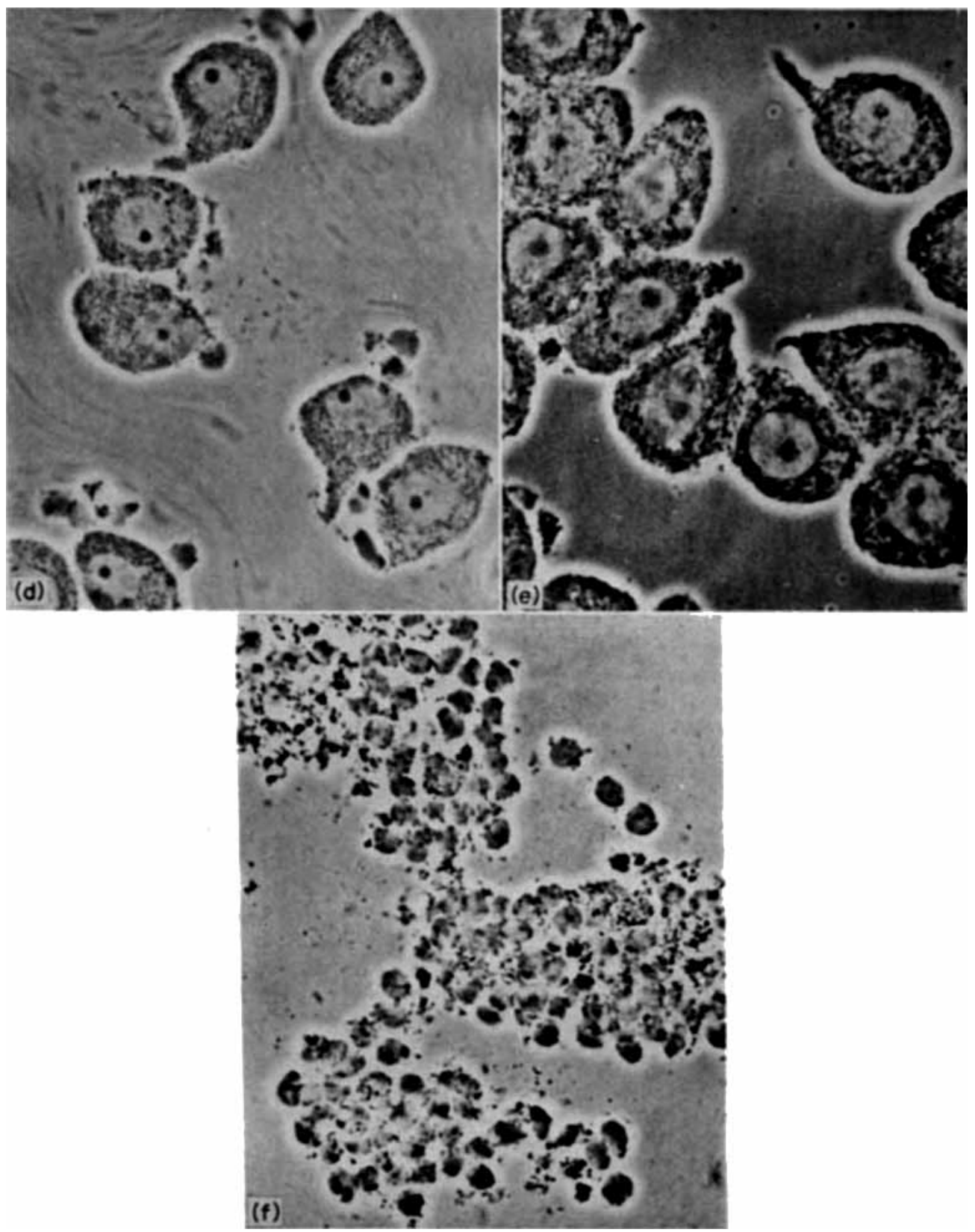

Fici. 2. (d) Purkinje cell bodies, 18 days. 3000 . (e) Purkinje cell bodies, 18 days. 4000 . (f) Granule cells. 15 days. $\because 3000$ 
volume of $0.30 \mathrm{M}$ sucrose in $1 "$ "BSA to $3 \cdot 3-4 \cdot 1 \mathrm{ml}$. care being taken to disperse all visible clumps of material by gentle up-and-down aspiration in the capillary pipette. From 2.3 to $3.2 \mathrm{ml}$ of the evenly suspended and diluted material were then lityered on a 1 wo-step gradient of $1 \mathrm{ml}$ of $2.30 \mathrm{M}$ sucrose in $1 "$ "BSA and $2 \mathrm{ml}$ of $1.90 \mathrm{M}$ sucrose in 1 " "BSA and the tubes were centrifuged in the $3 \times 5 \mathrm{ml}$ swing-out rotor of the MSF superspeed centrifuge or rotor SW 50.1 of the Spinco L2 centrifuge it 124.000 $\mathrm{g}$ for $2 \mathrm{~h}$. The Purkinje cell body fraction banded at the sample $-1.90 \mathrm{~m}$ sucrose in terface, whik the granule cell fraction was collected from the 1.90 \& 2.30 m sucrose interlace. The assessment of the purity of the two fractions was done by phase contrast micruscopy and cresyl violet staining of unfived preparations. Figure i outlines the principal features of the bulk-separation procedure in diagrammatic form.

\section{RESLI.TS}

Yield of cells

The procedure developed for the bulk-isolation of Purkinje cell bodies and granule cells was applied in this study to the cerchellar cortex of rats aged 1224 days. Although in preliminary experiments animals younger than 12 days were used. the procedure failed to yield morphologically identifiable. mature Purkinje cell bodies: on the contlary. these were quite readily demonstrable in the appropriate fraction derived from cerebellar cortices of animals 12 days or older. The yicld of granule cells was inversely related to that of the Purkinje cell hodies. being lowest on days 18-19.' Figures 2(a c) illustrate the general appearance of the fractions.

The results of repeated microscopic examinations indicate a rather small contribution to the Purkinje cell hody fraction of what appared to be Golgi cells and. very infrequently. of small clusters ( 3 - 5 cells) of granule cells. The contamination of the granule cell fraction was mainly due to the presence of cellular debris. capillary strands, and. occasionally, of damaged Purkinje cell bodies and naked nuclei. On the basis of the inspection of about 40 sets of Purkinje cell body and gramule cell lractions. isolated in Montpellier and in Ann Arbor. we estimate the former fraction to consist of at least $85 "$ ". Purkinje cell bodies and the latter of at least 9()$^{\prime \prime}$ aranule cells.

The yuantitative yield of the different cerebellar neurons was estimated by measuring the total RNA in all the fractions. We chose the total RNA content of a fraction as the best expression of the number of cells

\footnotetext{
${ }^{1}$ For the sake of convenience results obtained on two conseculive datys were pooled and are expressed as daypairs: e.g. 18-19 days refers to results obtained on days is or 19.
}

in it because RNA measurements best reflect the operational accomplishment of the bulk-isolation procedure, namely the microscopically demonstrable fact that it supplies intact Purkinje cell bodies and granule cells separated from one another and in sufficient amounts for subsequent analysis of their specific cellular and subcellular processes (SELLINGER \& AzCL'RRA. 19741. We preferred RNA over protein. not only for the obvious technical reason stated in Materials and Methods, but also because the total cerebellar protein content increases precipitously between post-natal days 12 and 21 (Golrdon et al.. 1973; Chanda et al., 1973) whereas that of RNA undergoes a much more moderate increase (GoLrixon et al.. 1973: CHANDA $e t$ al.. 1973). DNA was not selected despite the relative constancy of its concentration in the whole cerebellum (GOURDON et al., 1973, see however CHANI)A et al.. 1973) as well as in individual nuclei of Purkinje cell bodies between days 15 and 25 (SANI)RITtre et al.. 1967). because of the likelihood that DNA measurements could easily vitiate cell quantitation if the bulkisolated cell fractions contained unequal proportions of contaminating naked nuclei. Admittedly, the choice of RNA has some disadvantages as well since, in view of the unavailability of analytical data concerning possible variations in the RNA/DNA ratio of Purkinje cell bodies and granule cells during the period of postnatal development examined in this study, it is not possible to use the RNA content of a fraction as the unequivocal marker of the number of cells present in it. Hence, it is also impossible to determine at any time the enzymatic activity per cell. The RNA content of the mixed neuronal fraction diminished markedly with age up to days $18-19$, despite the increased amount of RNA recovered. after sieving of the tissuc, in the cerebellar suspension (column 3. Table 1). Table 1 further show's (column 4) that only a very small proportion of the available RNA appeared in the mixed neuronal fraction, namely 1.63 per cent on days 12-13 and about a third of that 0.54 per cent, on days 18 . 19. The partition of the mixed neuronal RNA also varied with age (columns 5 and 6 . Table 1), thus directly reflecting the improved yicld with age of the Purkinje cell body fraction orer the granule cell fraction. The recover of the mixed neuronal RNA between the Purkinje cell body and the granule cell fractions (column 7. Table 1) averaged about 78 per cent. there being no obvious reason which could account for the rather wide fuctuations in recovery observed with age. The single experiment for which useful data could be obtained on day 24 illustrates that the bulk-isolation procedure becones less efficient as the cerebellar cortex matures: this is clearly indicated by (a) the low initial RNA content of the cerchellar suspension. (h) the extremely poor yield of Pur- 
TARLF 1. RNA IN CERFBELLAR CELL FRACTIONS

\begin{tabular}{|c|c|c|c|c|c|c|}
\hline $\begin{array}{l}\text { Post-natal } \\
\text { age } \\
\text { (days) }\end{array}$ & $\begin{array}{l}\text { Cerebellar } \\
\text { cortex } \\
\text { weight* } \\
\text { (g) }\end{array}$ & $\begin{array}{c}\text { Cerebellar } \\
\text { suspension }(\mathrm{CS})^{\dagger} \\
(\mu \mathrm{g})\end{array}$ & $\begin{array}{c}\text { Mixed } \\
\text { neurons }(\mathrm{N}) \\
\underset{(0}{0})_{+}^{+}\end{array}$ & $\begin{array}{c}\text { Purkinje } \\
\text { cell bodies (P) } \\
\left(_{0}^{\circ}\right)^{k}\end{array}$ & $\begin{array}{c}\text { Granule } \\
\text { cells (G) } \\
(0) \text { ) }\end{array}$ & $\begin{array}{c}\text { Actual } \\
\text { recover } \\
\left(\begin{array}{c}0 \\
0\end{array}\right) \|\end{array}$ \\
\hline 1213 & $\begin{array}{c}1.66 \pm 0.042 \\
(n=7)\end{array}$ & $\begin{array}{c}4200 \pm 346 \\
(n=5)\end{array}$ & $\begin{array}{c}1 \cdot 63 \pm 0 \cdot 40 \\
(n=5)\end{array}$ & $\begin{array}{c}10 \cdot 1 \\
(n=4)\end{array}$ & $\begin{array}{c}89 \cdot 9 \\
(n=6)\end{array}$ & 61.6 \\
\hline $1+15$ & $\begin{array}{c}2 \cdot 26 \pm 0.070 \\
(n=7)\end{array}$ & $\begin{array}{c}5550 \pm 469 \\
(n=7)\end{array}$ & $\begin{array}{c}1 \cdot 22 \pm 0.25 \\
(n=5)\end{array}$ & $\begin{array}{c}16.9 \\
(n=5)\end{array}$ & $\begin{array}{c}83 \cdot 1 \\
(n=5)\end{array}$ & 83.4 \\
\hline $16-17$ & $\begin{array}{c}2 \cdot 56 \pm 0.045 \\
(n=5)\end{array}$ & $\begin{array}{c}5950 \pm 300 \\
(n=4)\end{array}$ & $\begin{array}{c}0.96 \pm 0.23 \\
(n=3)\end{array}$ & $\begin{array}{c}34 \cdot 7 \\
(n=3)\end{array}$ & $\begin{array}{c}65 \cdot 3 \\
(n=3)\end{array}$ & $59 \cdot 6$ \\
\hline $18-19$ & $\begin{array}{c}2 \cdot 82 \pm 0 \cdot(146 \\
(n=8)\end{array}$ & $\begin{array}{c}6240 \pm 384 \\
(n=9)\end{array}$ & $\begin{array}{c}0.54 \pm 0.13 \\
(n=4)\end{array}$ & $\begin{array}{c}70 \cdot 4 \\
(n=7)\end{array}$ & $\begin{array}{c}29 \cdot 6 \\
(n=4)\end{array}$ & $80 \cdot 0$ \\
\hline 24 & $\begin{array}{c}2.97 \\
(n=1)\end{array}$ & $\begin{array}{c}4650 \pm 530 \\
(n=2)\end{array}$ & $\begin{array}{c}0.06 \\
(n=1)\end{array}$ & $100 \cdot 0$ & 0 & 107.0 \\
\hline
\end{tabular}

* Of 20 animals. Mean value \pm S.E.M. are given. The number of determinations $(n)$ is given in parentheses.

+ After sieving through the last nylon mesh. Mean values \pm S.E.M. are given.

$\ddagger$ As percentage of the RNA in fraction CS. Mean values \pm S.E.M. are given.

$\$$ As percentage of the RNA in fraction $N$. Mean values are given.

iा $(P+G / N) \times 100$, except for 24 days where $(P / N) \times 100=107 \%$. Mean values are given.

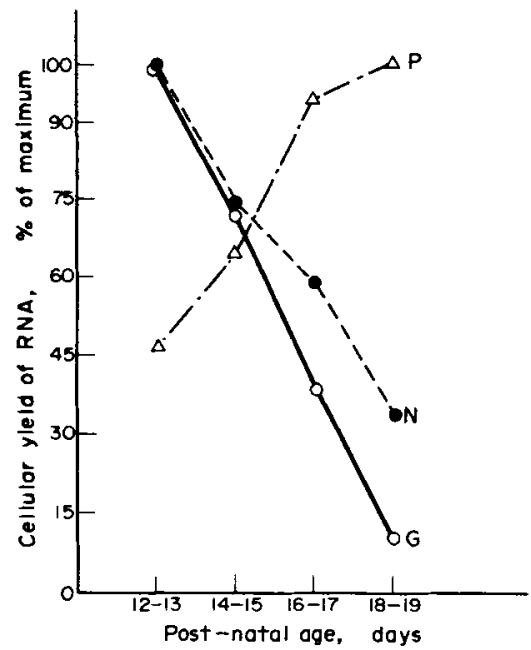

Fig. 3. The effect of post-natal age on the RNA content of the isolated fractions. The mixed neuronal (N). Purkinje cell body $(P)$ and granule cell $(G)$ fractions were prepared from 20 cerebellar cortices (see Methods for details) and RNA was determined according to Fleck \& BegG (1965). The ordinate values refer to maximal recoveries in relation to the RNA of the unfractionated cerebellar suspension made equal to 100 per cent. The actual values (in \%) were: Fractions $N$ and $G: 1.63$ and 1.56 on days $12-13$ and Fraction P: 0.42 on days $18-19$. See Table 1 for the number of determinations for each fraction.

kinje cell bodies, and (c) the total absence of granule cells. The inverse age dependence of the yield of RNA and thus, operationally, of the Purkinje cell bodies and the granule cells. is illustrated in Fig. 3 which shows the common downward trend of the mixed neuronal and the granule cell RNA on the one hand and the highly specific upward trend of the Purkinje cell body RNA on the other.

\section{Succinate-INT-reductase}

Table 2 illustrates the developmental pattern of cerebellar mitochondrial succinate-INT-reductase (column 2) and the partition of the activity between the Purkinje cell bodies and the granule cells. while Fig. 4 depicts the developmental pattern of the specific activity of this enzyme. Column 3 of Table 2 shows that the recovery of the enzyme in the mixed neuronal fraction decreased with age and that the decrease paralleled that shown by the RNA (column 4, Table 1). The partition with age of succinate-INT-reductase between the Purkinje cell body and the granule cell fractions (columns 4 and 5, Table 2) also paralleled that of the RNA (columns 5 and 6, Table 1). The relationship between its activity in either of these fractions and their RNA content, which is a measure of its specific activity, showed an inverse age dependence. Figure 4 further shows that between days 12 and 15 , but not later, the specific activity of succinate-INT-reductase of Purkinje cell bodies exceeded that of the enzyme in the granule cells by $2-3$-fold, while that of the enzyme in the mixed neuronal fraction remained intermediate between the two cell fraction values.

\section{Acetylcholinesterase}

The activity of cerebellar acetylcholinesterase expressed as $\mathbf{A}_{412}$ units per 20 cerebella in the cerebellar suspension (column 2, Table 3) or calculated per gram of cerebellar cortex (see column 2, Table 1) increased 
TABLE 2. SUCCINATE-INT-REDUCTASE IN CEREBELLAR CELL FRACTIONS

\begin{tabular}{|c|c|c|c|c|c|c|}
\hline $\begin{array}{l}\text { Post-natal } \\
\text { age } \\
\text { (days) }\end{array}$ & $\begin{array}{c}\text { Cerebellar } \\
\text { suspension (CS)* } \\
\left(\mathrm{A}_{490} \text { units }\right)\end{array}$ & $\begin{array}{c}\text { Mixed } \\
\text { neurons (N) } \\
\left(\mathbf{A}_{490}\right)\end{array}$ & $(\%) \dagger$ & $\begin{array}{c}\text { Purkinje } \\
\text { cell bodies }(\mathrm{P}) \\
(\%)_{+}^{+}\end{array}$ & $\begin{array}{c}\text { Granule } \\
\text { cells }(\mathrm{G}) \\
(\%)_{+}^{+}\end{array}$ & $\begin{array}{c}\text { Actual } \\
\text { recovery } \delta \\
(\%)\end{array}$ \\
\hline $12-13$ & $\begin{array}{c}372 \pm 31 \\
(n=6)\end{array}$ & $\begin{array}{c}4.74 \pm 0.62 \\
(n=7)\end{array}$ & $1 \cdot 27$ & $\begin{array}{c}35 \cdot 0 \\
(24 \cdot 6-51 \cdot 8)\end{array}$ & $\begin{array}{c}65 \cdot 0 \\
(48 \cdot 2-75 \cdot 4)\end{array}$ & $82 \cdot 7$ \\
\hline $14-15$ & $\begin{array}{c}547 \pm 47 \\
(n=7)\end{array}$ & $\begin{array}{c}5 \cdot 43 \pm 0 \cdot 98 \\
(n=6)\end{array}$ & 0.99 & $\begin{array}{c}36 \cdot 7 \\
(31 \cdot 2-45 \cdot 4)\end{array}$ & $\begin{array}{c}63 \cdot 3 \\
(54 \cdot 6-68 \cdot 8)\end{array}$ & 87.0 \\
\hline $16-17$ & $\begin{array}{c}696 \pm 49 \\
(n=5)\end{array}$ & $\begin{array}{c}4 \cdot 12 \pm 0 \cdot 50 \\
(n=4)\end{array}$ & 0.59 & $\begin{array}{c}50-9 \\
(35 \cdot 6-63 \cdot 1)\end{array}$ & $\begin{array}{c}49 \cdot 1 \\
(36 \cdot 9-64 \cdot 4)\end{array}$ & 802 \\
\hline $18-19$ & $\begin{array}{c}918 \pm 70 \\
(n=9)\end{array}$ & $\begin{array}{c}4 \cdot 38 \pm 1 \cdot 46 \\
(n=6)\end{array}$ & 0.48 & $\begin{array}{c}61 \cdot 0 \\
(41 \cdot 7-84 \cdot 1)\end{array}$ & $\begin{array}{c}38 \cdot 0 \\
(15-9-58-3)\end{array}$ & 770 \\
\hline 24 & $\begin{array}{c}1610 \\
(n=1)\end{array}$ & - & - & - & - & - \\
\hline
\end{tabular}

* Cerebellar cortex mince prepared from 20 animals and sieved through all nylon meshes. Mean values \pm S.E.M. are given. The number of determinations $(n)$ is given in parentheses.

+ As percentage of the enzyme activity in fraction CS. Mean values are given.

+ As percentage of the enzyme activity in fraction $N$. Mean value with range is given.

$\$(P+G / N) \times 100$.

rather moderately over the 12-19 day period but then underwent an apparent two-fold increase between days $18-19$ and 24 . The recovery of acetylcholinesterase in the mixed neuronal fraction (column 3, Table 3) decreased with age in a manner quite analogous to that noted in the case of RNA and succinate-INT-reductase (Tables 1 and 2). The partition of the enzyme between the Purkinje cell body and the granule cell fractions differed, however, for it remained rather constant over the entire time period studied, namely at about 35 per cent in the former fraction and at about 65 per cent in the latter fraction (columns 4 and 5, Table 3). Another feature of interest was the different distribution with age of the true acetylcholinesterase in the two cell-fractions (Fig. 5), for while this component accounted for no more than 45 per cent of the total acetylcholinester- ase activity in the mixed neuron fraction, it represented a much smaller proportion (as low as 20 per cent on days $14-15$ ) in the Purkinje cell body fraction and a much greater proportion (up to 65 per cent on days 18-19) of the total acetylcholinesterase in the granule cell fraction.

Figure 6 illustrates the time course of the specific activity of acetylcholinesterase in the different cell fractions. An opposite trend characterized the specific activity in the Purkinje cell body fraction, where its values decreased throughout the 12-13 to 18-19 day period and in the granule cell fraction, where, on the contrary, the specific activity increased about three fold during the same time. A striking feature of these findings was the rather uneventful pattern of the specific activity time course in the parent, mixed neuron fraction. It

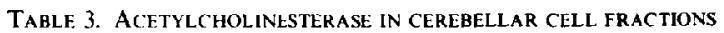

\begin{tabular}{|c|c|c|c|c|}
\hline $\begin{array}{l}\text { Post-natal } \\
\text { age } \\
\text { (days) }\end{array}$ & $\begin{array}{c}\text { Cerebellar } \\
\text { suspension }(C S)^{*} \\
\left(A_{412} \text { Units }\right)\end{array}$ & $\begin{array}{c}\text { Mixed } \\
\text { neurons (N) } \\
(0) t\end{array}$ & $\begin{array}{c}\text { Purkinje } \\
\text { cell bodies (P) } \\
(\%)\end{array}$ & $\begin{array}{c}\text { Granule } \\
\text { cells }(G) \\
(\%)\end{array}$ \\
\hline $12-1.3$ & $\begin{array}{c}376 \pm 78 \\
(n=4)\end{array}$ & $1 \cdot 15 \pm 0.26$ & $\begin{array}{c}30 \cdot 9 \\
(7 \cdot 2-48 \cdot 0)\end{array}$ & $\begin{array}{c}69 \cdot 1 \\
(52.0-92 \cdot 8)\end{array}$ \\
\hline $14-15$ & $\begin{array}{c}505 \pm 85 \\
(n=3)\end{array}$ & $0.73 \pm 0.18$ & $\begin{array}{c}25 \cdot 6 \\
(14 \cdot 1-39 \cdot 8)\end{array}$ & $\begin{array}{c}74 \cdot 4 \\
(60.285 .9)\end{array}$ \\
\hline $16-17$ & $\begin{array}{c}576 \pm 91 \\
(n=3)\end{array}$ & $0.36 \pm 0.02$ & $\begin{array}{c}40-5 \\
(17.9-57.2)\end{array}$ & $\begin{array}{c}59 \cdot 5 \\
(42-8-82 \cdot 1)\end{array}$ \\
\hline $18-19$ & $\begin{array}{c}579 \pm 76 \\
(n=5)\end{array}$ & $0.42 \pm 0.13$ & $\begin{array}{c}25 \cdot 6 \\
(8 \cdot 3-49 \cdot 0)\end{array}$ & $\begin{array}{c}74.4 \\
(51 \cdot 0-84.5)\end{array}$ \\
\hline 24 & $\begin{array}{c}1290 \\
(n=1)\end{array}$ & 0.17 & - & - \\
\hline
\end{tabular}

* Cerebellar cortex mince prepared from 20 animals and sieved through all nylon meshes. Mean values \pm S.E.M. are given.

+ As percentage of the enzyme activity in fraction CS. Mean values are given.

$\$$ As percentage of the enzyme activity in fraction $\mathrm{N}$. Mean value with range is given.

The number of determinations $(n)$ is given in parentheses and is the same for all columns. 


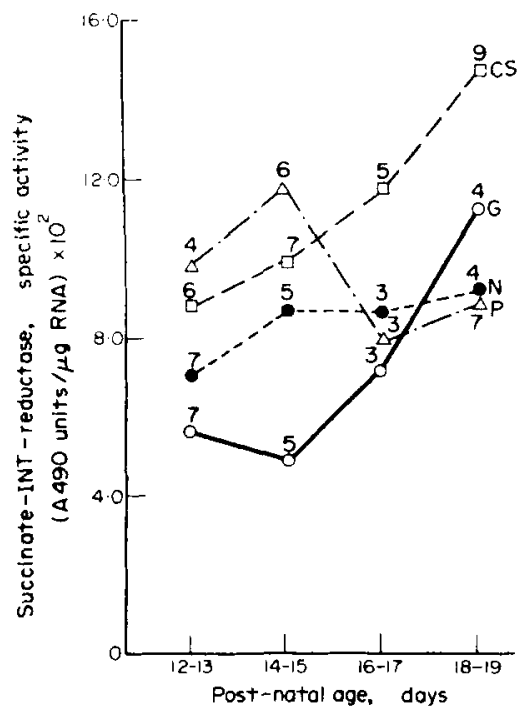

Fki. \& The post-natal development of succinate-INTreductass in cercbellar cellular fractions. The cerebellar suspension (Fraction CS) and the cellular fractions were prepared as described in Methods and the activity of succinateINT-reductase determined. The ordinate values are expressed as units of $A_{+\infty}$ activity per $\mu \mathrm{g}$ of RNA. The numbers above the symbols refer to the actual numbers of specific activity determinations. These numbers naty differ from the corresponding sets of numbers listed in Tables 1 and 2. Thus, for example, while the numbers above the symbols ploting curve ('S signily that the means of the actually determined $A_{+\infty}$ activity values were divided by the mealns of an equal number of actually determined RNA walues for each time point. the number 4 above the $18-19$ symbol on the curve labelled $N$ signifies that, although a intal of $6 \mathrm{~A}_{+}$activity determinations were made (column 3. Table 21. RNA was determined only in 4 out of the 6 experiments (column + . Table 1). The specific activity indicated wils thus calculated by dividing the mean value obtaincd from + activity measurements by the mean value of 4 RNA measurements and hence is different from the value that would be oblained by direct calculation from columns 4 and 3 of Tables $I$ and 2. respectively. The \pm s.t.M. $\times 10^{2}$ were as follows (values listed in chronological order for each fraction): Fraction $N: 1.35: 1.97,130,1.56$ : Fraction P: 1-80:1 38.1-10.0.15: and Fraction G:0.82.0.50. $1 \cdot 48.2 .9$.

should also be noted that the observed relationship between the specific activities of acetylcholinesterase in the Purkinje cell body and the granule cell fractions stands in direct contrast to the respective changes in the RNA content of the bulk-isolated fractions. Thus it may be seen that as the yield of the Purkinje cell body fraction increased (Fig. 3), the specific activity of

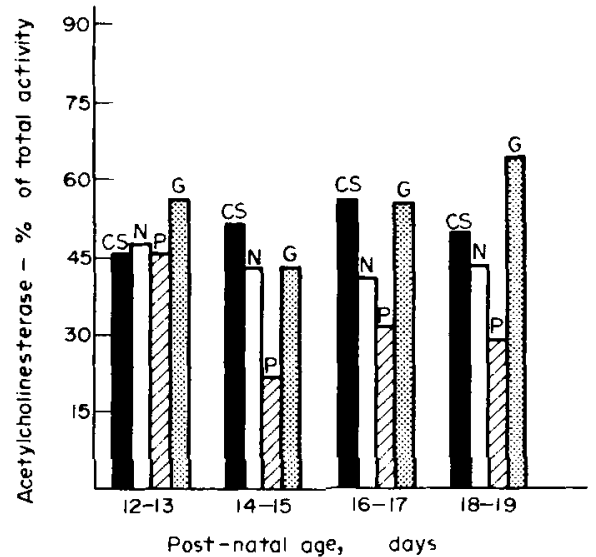

Fig. 5 . The effect of age on the contribution of true acetylcholinesterase to the total cholinesterase activit of isolated cercbellar ceilular fractions. All fractions were prepared and the tolal and true acelylcholinesterase ativities determined as described in Methods. For numbers of experiments carried out to obtain the mean vilues plotted. see column 2 . Table 3. The \pm S.l:M. values were as follows (values listed in chromological order for each fraction): Fraction CS: 2.55 , $5 \cdot 7.5 \cdot 8.45$ : Fraction $N: 0.74 .12 .60 .63$ : Fraction $P: 9 \cdot 4$. 1.5. 24.6.3: Fraction G: 7.0, 10).3, 15.9, 3-3.

its acetylcholinesterase decreased (Fig. 6), the reverse situation holding true for the granule cell fraction.

\section{DISCUSSION}

In this report we describe a bulk-isolation procedure which permits the preparation of two highly enriched cerebellar fractions, each predominantly containing a single neuronal cell type. The lighter of these fractions consists almost exclusively of Purkinje cell bodies. while the heavier one consists almost entirely of granule cells. The procedure is both an extension and a refinement of the procedure described previously for the preparation of nerve cell bodies and glial cells from the cerebral cortex (SFLLINGIR et al.. 1971; SELLINGLR \& AzCURRA. 1974), for it also avoids the use of proteolytic enzymes (BarkLeY at al. 1973) and or the exposure of the cerebellar tissue mince to temperatures exceeding that of crushed ice (Yavagihara \& HaMBHRGER. 1973). It thus resembles most closely, at least in its initial phase, although not in its entirety, the procedure of CoHEN et al. (197.3).

The results of Table 1 show that although the yield of RNA in the mixed neuron and the granule cell fractions diminished with age, the Purkinje cell body fraction represented an ever-increasing portion of the total neuronal RNA. a finding which gains added significance when one considers the vast numerical prepon- 


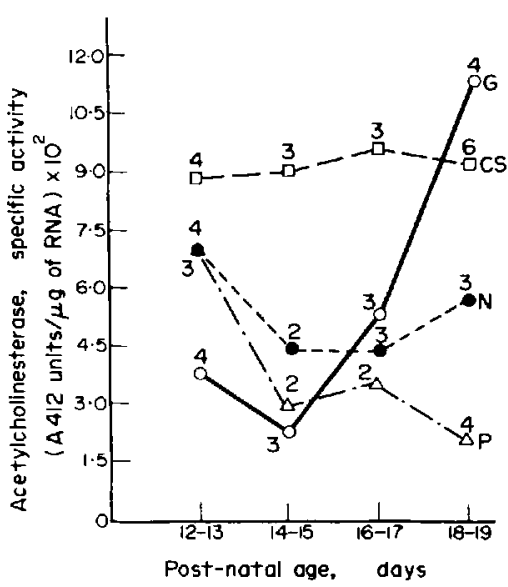

Fig. 6. The post-natal development of acetylcholinesterase in cerchellar cellular fractions. All fractions were prepared and the activity of acetylcholinesterase determined as described in Methods. The ordinate values are expressed as $A_{41}$, units per $\mu g$ of $\mathbf{R N A}$. The numbers above the symbols relier to the actual number of specific activity determinations. Sce legend to Fig. 4 for additional explanatory comments. Because the number of determinations was rather small. the range, instead of the \pm S.E.M., of the specific activity values, is given. These were as follows (listed. $\times 10^{2}$, in chronologicil order for eatch fraction): Fraction $\mathrm{N}: 3 \cdot 3$ $10 \cdot 7 ; 1 \cdot 7-7 \cdot 8 ; 2 \cdot 9-7 \cdot 0 ; 2 \cdot 1-8 \cdot 8$ : Fraction $P: 1 \cdot 0-14 \cdot 3: 1 \cdot 1-$ $4 \cdot 8: 3 \cdot 3$ 3.7:0.3-3.9: Fraction G: 1.0-5.5:1.1 4.6:2.4-8.8: $6 \cdot 8-21 \cdot 8$.

derance of granule over Purkinje cells in the intact cerebellar cortex (Fox \& Barnakl, 1957: Cohen et al.. 1973). The point is confirmed by a calculation which reveals that on days $12-13$ the Purkinje cell body fraction contained 0.16 per cent $\left(10.1^{\circ}\right.$, of $1.63^{\circ}{ }_{i}$, see Table 1) of the $4200 \mu \mathrm{g}$ of RNA present in the cerebellar suspension, or at total of $6.75 \mu \mathrm{g}$. while on days $18-19$ the RNA content of this fraction rose to $23.6 \mu \mathrm{g}$. This is further illustrated graphically in Fig. 3 which plots the $\mathrm{RNA}$ recoveries in the three cellular fractions (as per cent of their respective maxima) against age. Recalculating the RNA values per gram of cerebellar cortex reveals 4.05 $\mathrm{ng} \mathrm{g}$ in the Purkinje cell body fraction on days 1213 against $8.30 \mu \mathrm{g} / \mathrm{g}$ on days 18.19 . or an approximate 100 per cent increase in yield in a weeks time. The restons underlying such a converse relationship betuecn age and yicld derive. most likely, from the prevaliting state of the two cell types in situ. Thus the yield of Purkinje cell bodies improves with age because between disy 12 and 19 these cells lose their perisomatic proces $x$ 's and become free of their temporary entallglement and contacts with climbing fibers. two features which facilitate their unencumbered passage through the presized nylon filters used for their isolation. Conversely, the yield of the granule cells decreased during the same period because these cells begin to engage in the formation of dense cerebcllar glomeruli at about 1415 days, a feature which renders their isolation by the bland procedure described in the present study more difficult by the day. The success of the bulk-isolation procedure correlated well therefore with the chromological sequence of events characteristic of cerebellar maturation in the rat, a finding which constitutes the principal trademark of its validity and which guarentees its future usefulness in cellular neurochemistry research.

The development of the mitochondrial enzyme succinate-INT-reductase shows a steady increase in the cerebellar suspension (Garcia Argiz et al.. 1967) (column 2. Table 2). while concomitantly its recovery in the Purkinje cell body fraction increased between days 12 and 19 from 35.0 to 61.0 per cent. The specific activity profile of the enzyme reflected the recovery data (Fig. 4). in all except the Purkinje cell body fraction. in which it actually reached values that were lower on days $18-19$ than on days 12-13 despite the increased yield of RNA in this fraction (Tablc 1). Our findings thus demonstrate that during the crucial period of post-natal development the specific activity of mitochondrial succinate-INT-reductase undergoes characteristic but different changes in two functionally different cerebellar cell types. a discovery of cellular specificity which could only be made because the bulkisolation procedure made these cells a vailable in the form of separated populations. Our findings agree with the numerous histoenzymatic observations (see Legrand. 1967) which show that Purkinje cell bodies stain very intensely during the first ten days and less intensely by the end of the second week. when a diffuse succinate-INT-reductase reaction begins to be observed in the molecular layer and when the staining appears in the glomeruli cerebellosi. It thereforc appears possible to suggest that the decrease of the specific activity of succinate-INT-reductase in the Purkinje cell body fraction may be related to a decrease of enzyme per cellular body. for the number of mitochondria in the cell body may indeed be diminishing as a result of the intensive grow th and branching of the Purkinjc cell dendritic tree.

Table 3 illustrates the fact that the post-natal development of acetyleholinesterase proceded in spurts. since after an increase from 376 to 505 units between dalys 12 and 15 (column 2). the activity stabilized at about 575 units between days 16 and 19 and then doubled again by day 24. As noted for RNA and succintileINT-reductase (Tables 1 and 2) the yield of acelylcholinesterase in the mixed neuron fraction also decrealsed 
with age. However, unlike with RNA and succinateINT-reductase, its partition between the Purkinje cell body and the granule cell fractions proved to be relatively age-independent, there being on the average between 1.5 .3 times more enzyme in the granule cell fraction than in the Purkinje cell body fraction (Table 3). An additional constant feature was the lower contribution of true acetylcholinesterase activity in the Purkinje cell body fraction than in the granule cell fraction (Fig. 5). Finally, Fig. 6 illustrates for acetylcholinesterase what Fig. 4 depicted for succinate-INT-reductase, i.e. an age-related increase in specific activity in the two fractions whose yield diminished with age (the mixed neuronal and the granule cell fractions) and a decrease in the fraction whose yield increased with age. i.e. the Purkinje cell body fraction. The latter observation agrees with and complements the recent histoenzymatic findings of CLOS (1972), who noted that cholinesterase activity disappears in Purkinje cells of the nodulus by post-natal day 14 . Whether the low acetylcholinesterase activity which associates with the Purkinje cell body fraction beyond 14 days (Fig. 6) reflects contamination of this fraction by the highly reactive Golgi cells or by highly active synaptic fragments cannot be ascertained at this time. It is to be noted that by day 14 the cerebellar glomeruli stain positively for cholinesterase activity and that the staining increases with time. an observation entirely consistent with the timing of the steep increase of the specific activity of acetylcholinesterase in the granule cell fraction (Fig. 6).

In conclusion our findings reveal a different time course for the early post-natal development of mitochondrial succinate-INT-reductase and of the membrane-bound acetylcholinesterase in the Purkinje cell bodies and the granule cells of the rat cerebellar cortex. Whereas in the Purkinje cell bodies the specific activity of both enzymes exhibited a downward trend during the time period under study (Fig. 4 and 6), the converse was found to characterize their development in the granule cells. The feasibility of the present study and of similar ones in the future requires, as a condition sine qua non, the availability of the Purkinje and granule cell populations separated from one another and in amounts sufficient for comparative biochemical analysis. Figures 1 and 2 document the fulfilment of this condition.

\section{REFERENCES}

Altman J. \& Das G. D. (1970) Exp. Neurol. (Minneapolis) $28,11-34$
Barkley D. S., Rakic' L. J.. Chaffee J. K. \& Wong D. L. (1973) J. Cell Physiol. 81, 271-280.

Chandra R.. WoOdward D. J. \& Griffin S. (1973) J. Neurochem. 21, 547-555.

Clos J. (1972) C. r. hèd. Séanc. Acad. Sci., Paris 275, 29172920.

Clos J. \& Legrand J. (1973) Brain Res. 63, $450-455$.

Clos J.. Rebière A. \& Legrand J. (1973) Brain Res. 63, 445449.

Cohen J., Mareš V. \& Lodin Z. (1973) J. Neurochem. 20, 651-657.

Ellman G. L., Courtney K. D., Andres V. \& FeatherStONe R. M. (1961) Biochem. Pharmac. 7, 88-95.

FLeCK A. \& BEgG D. (1965) Biochim. biophys. Acta 108, 333342.

Fox C. A. \& Barnard J. W. (1957) J. Anat. 91, 299-313.

García Argiz C. A.. Pasul ini J. M.. Kaplún B. \& Gomez C. J. (1967) Brain Res. 6, 635-646.

Gourdon J., Clos J., Coste C.. Dainat J. \& Legrand J. (1973) J. Neurochem. 21, 861-871.

HiRsCh H. E. (1972) J. Neurochem. 19, 1513-1517.

Idoyaga-Vargas V., Santiago J. C.. Petiet P. D. \& SelLINGER O. Z. (1972) J. Neurochem. 19, 2533-2544.

JohNSON D. E. \& Sellinger O. Z. (1971) J. Neurochem. 18, 1445-1460.

Legrand J. (1967) Archs Anat. micr. Morph. exp. 56. 205 244.

Medzihradsky F.. Sellinger O. Z., NandhasRi P. S. \& Santiago J. C. (1972) J. Neurochem. 19, 543-545.

Poduslo S. E. \& Norton W. T. (1972) in Research Methods in Neurochemistry (MARKS N. \& RODNiGHT R., eds.) Vol. 1, pp. 19-32. Plenum Press. New York.

Rebière A. \& Legrand J. (1970) Brain Res. 22, 299-312.

Rebière A. \& Legrand J. (1972) Archs Anat. micr. Morph. exp. 61, 105, 126.

Sandritter W., Nováková V., Pilny J. \& Kiefer Z. (1967) Z. Zellforsch. 80, 145-152.

Sellinger O. Z. \& Azcurra J. M. (1974) in Rescarch Methods in Neurochemistry (MARKs N. \& RODNIGHT R., eds.) Vol. 2, pp. 3-38. Plenum Press, New York.

Sellinger O. Z., Azcurra J. M., Johnson D. E., Ohlsson W. G. \& Lodin Z. (1971) Nature New Biol., Lond. 230 , 253-256.

Sellinger O. Z. \& Hiatt R. A. (1968) Brain Res. 7, 191-200.

Sellinger O. Z., LODin Z. \& AzCurRa J. M. (1972) Bruin Res. 42, 159-175.

Sellinger O. Z. \& Santiago J. C. (1972) Neurobiolog. 2, 133-146.

Sellinger O. Z., Santiago J. C. Sandos M. A. \& FurinSlOat B. (1973) Biochim. biophys. Acta 315, 128-146.

Shuter E. R.. Robins E.. Freeman M. L. \& Jungalwala F. B. (1970) J. Histochem. Cytochem. 18, 271-277.

Yanagimara T. \& Hamberger A. (1973) Brain Res. 59, $445-$ 448. 